\title{
Creating hyssop phytocenoses in anthropogenically transformed ecosystems
}

\author{
Petro Dobrovolskyi ${ }^{1}$, Larysa Andriichenko ${ }^{1}$, Tetiana Kachanova ${ }^{2 *}$, and Tetiana \\ Manushkina $^{2}$ \\ ${ }^{1}$ Mykolaiv State Agricultural Research Station of the Institute of Irrigated Farming NAAS, 57217 \\ Mykolaiv, Ukraine \\ ${ }^{2}$ Mykolayiv National Agrarian University, 9 George Gongadze St., 54020 Mykolaiv, Ukraine
}

\begin{abstract}
The aim of the article is to define hyssop (Hyssopus officinalis) 'Markiz' cultivar capacity parameters aimed at recultivating degraded soils, alkali soils, sloping lands, local landscaping of technologically polluted areas, which will promote improvement of anthropogenically transformed ecosystems. To implement such practical measures comprehensive approach should be used while selecting agronomic measures for growing crops by applying fertilizers $\left(\mathrm{N}_{60} \mathrm{P}_{60}\right.$ broadcast, $\mathrm{N}_{30} \mathrm{P}_{30}$ broadcast $+\mathrm{N}_{30} \mathrm{P}_{30}$ with irrigation water during boot stage) and retaining soil moister per 30-40 cm depth on the level of $80-70-70 \%$ MHC. In these circumstances, stable agrophytocenosis is formed with optimal plants capacity parameters and crops of dry floral materials at the level of 52.6-53.7 c/ha. After the first mowing at the end of June, shoots are growing and flowering during the last August decade and beginning of September. However, phytomass yield is twice lower compared to the first mowing.
\end{abstract}

\section{Introduction}

Reclamation and return to biological cycle of industrially damaged areas is a condition for stable development of our country regions. According to the Law of Ukraine "On basic principles (strategy) of state environmental policy of Ukraine for the period up to 2030" reclamation and rehabilitation of areas affected by anthropogenic activities is a priority of national environmental policy. Technologically damaged areas, as a rule, are environmentally dangerous. At polluted areas it is impossible to grow plants aimed at consumption, as well as there is a limit for growing pasture crop. There is also unfavourable ecological situation in Mykolaiv region - industrial area, where there are a lot of pollutants, industrial wastes. Restoration is also required by lands, which were occupied by mining plants, hydraulic dumps and industrial waste storages, transport communications of closed enterprises, etc. $[1,2]$. Dumps are difficult for reclamation, and plants natural recovery is quite slow. Current state of region soil cover (degradation, humus loss, water and wind erosion, etc.) can be characterized as being near ecological catastrophe. In a wide range of measures to restore damaged areas and protect environment, much attention is paid to

* Corresponding author: kachanova0909@gmail.com 
revitalization of anthropogenically altered ecosystems, in particular, phytomelioration and reclamation, which involve development and implementation of comprehensive work to restore aesthetic value and productivity of anthropogenically altered landscapes. In this case, growing plants of natural phytomeliorants-soil fixers might be supportive. Hyssop is considered one of these plants - perennial shrub, characterized by a wide ecological amplitude. It is also grown as a spicy-flavored crop, used in the canning, alcoholic beverage industry, as well as nectar-bearing plant [3, 4]. Like most spicy-aromatic plants, hyssop has medicinal properties. A number of researchers [5-7] noted antioxidant, emollient, antihisticidal, astringent, tonic, wound-healing effect of hyssop. Hyssop extract and essential oil showed moderate antioxidant and antimicrobial activity, as well as antifungal and antiviral properties in vitro. Herbal raw materials are used to treat acute respiratory infections, asthma, anemia, neurosis, rheumatism, angina, stomatitis, as wound healing agent $[3,6,7]$.

Hyssop - is a typical xerophyte well-adjusted to drought, undemanding to growing conditions [8]. Hyssop's dispersal at technologically polluted areas is caused by this sample's small demands to soil conditions of growing. Due to this, hyssop creates preconditions for further phytocenoses dumps development at such areas in 7-10 years close in structure to natural steppe. Climate and soil conditions at southern part of Steppe of Ukraine meets necessary requirements for growing hyssop [9, 10]. Plants are hardy and drought tolerate. This species seeds are also characterized by high viability, laboratory germination of seeds at the level of $95-97 \%$ does not change during three or four years of storage.

For implementing Hyssopus officinalis L. into industrial production, authors of the article have conducted preliminary research (2016-2017) to study this sample's adaptive capacity when grown in natural steppe ecosystem, on the basis of farming enterprise "Fedosov" Kazanka rayon of Mykolaiv region on 0,5 hectares territory, cultivar 'National'. It is stated that hyssop is a valuable spicy-aromatic sample, which according to its biological features, requirements for soil and climatic conditions can be grown in Steppe of Ukraine, providing a high yield of flower mass being used in medicinal pharmacology. On heavy loamy, moist soils, the plant grew badly. On the other hand, on areas with southern slope, plants created 74 stalks on average, their height was $65.9 \mathrm{~cm}$, leaf mass was 1053 $\mathrm{h} / \mathrm{m} 2$, crops water consumption ratio reached $1951 \mathrm{~m} 3 / \mathrm{t}$, dry raw materials yield - up to 40 $\mathrm{c} /$ ha including essential oil $0.85 \%$, ascorbic acid $-104.6 \mathrm{mg} \%$. This experience has also been used in current experiment. However, peculiarities forming crop capacity in anthropogenically transformed ecosystems have not been clarified so far, experimental data predicting further growing Hyssopus officinalis on depleted and degraded soils are absent, in Mykolaiv region such studies have not been conducted.

\section{Materials and methods}

The aim of the article was to define plant's capacity parameters on the basis of studying hyssop biology, which will contribute to obtaining flower mass on the level of 40-50 c/ha and develop measures for its effective growing under the conditions of technogenically transferred lands of Mykolaiv region. Experimental research has been conducted on the territory of Steppe of Ukraine, on lands of Mykolaiv State Agricultural Station of the Institute of Irrigated Agriculture of the National Academy of Agrarian Sciences of Ukraine, ecological conditions (latitude $46^{\circ} 51^{\prime} \mathrm{N}$ and longitude $32^{\circ} 59^{\prime} \mathrm{E}, 52 \mathrm{~m}$ above sea level), during 2018, 2019 and 2020 years. Climate - is continental, characterized by sharp and frequent fluctuations in annual and monthly air temperatures, large heat reserves and aridity. Land for the experiment represented deserted area in abandoned state, which was gradually turning into spontaneous landfill. 
Thus, the area under experiment was a convenient model object, which served as a baseline for development of measures to optimize technogenically transformed region into a structural organization of hyssop phytocenetic cover. Recreational phytomelioration is possible on such technogenically transformed lands with unchanged terrain, which includes the following types of work: investigating damaged territory for the purpose of suitability for growing plants; application of mineral or organic fertilizers; sowing of cover vegetation; carrying out agrotechnical care of plants.

Reclaimed lands productivity is related to humus content, agrochemical and mechanical content of arable soil layer, due to soil contamination degree with heavy metals and other hazardous substances. According to the analysis, experimental field represented southern chernozem with a fairly high humus content. According to the content of nutrients available forms, soil was characterized by low supply of nitrogen, average supply of labile phosphorus, high supply of exchangeable potassium (Table 1).

Table 1. Soil analysis report of the experimental site, per $30 \mathrm{~cm}$ of soil depth.

\begin{tabular}{|l|c|}
\hline Silt, \% & 33.6 \\
\hline Clay loam, \% & 55.1 \\
\hline Organic matter, \% (for Tyurin) & 2.1 \\
\hline Bulk density, g/cm ${ }^{3}$ & 1.35 \\
\hline Nitrate nitrogen $\mathrm{N}_{\mathrm{NO}}$, $\mathrm{mg} / \mathrm{kg}$ (for Tyurin-Kononova) & 4.2 \\
\hline Phosphorus, $\mathrm{mg} / \mathrm{kg}$ (for Chirikov) & 142.5 \\
\hline Available potassium, mg/kg (for Chirikov) & 182.0 \\
\hline Soil pH (DSTU ISO 10390:2007) & 6.8 \\
\hline Sum of absorbed bases $(\mathrm{Ca}+\mathrm{Mg}$ ), mg-eq per $100 \mathrm{~g}$ & 30.0 \\
\hline Permanent wilting point, \% by weight & 11.7 \\
\hline Moisture holding capacity, \% (MHC) & 24.8 \\
\hline
\end{tabular}

Exceedance of heavy metals, radionuclides, pesticides in the soil was not defined. Thus, researched territory appeared to be favourable for hyssop growing. Crop production area $162 \mathrm{~m} 2$, accounting $-5 \mathrm{~m} 2$. Subject of research was hyssop 'Markiz' cultivar, which has a blue-violet corolla colour. Sowing was carried out in autumn 2017 according to experimental scheme to the depth of $2-3 \mathrm{~cm}$ with precision sowing seeder Agricola italiana SN-2-290. Experimental scheme included two factors: factor A (fertilizer): without fertilizers (control), N60P60 broadcast, N30P30 broadcast + N30P30 with irrigation water. By factor B (irrigation method), two levels of crop moisture were studied: $80-70-70 \%$ MHC and 90-80-70\% MHC. Drip irrigation was used to irrigate land plots. Pre-irrigation control of soil moisture during periods of plant development was performed with the help of tensiometers, irrigation was stopped 14 days before harvesting of floral materials. Mowing of ground mass was carried out in the phase of mass flowering, which was then dried under cover.

\section{Results}

Autumn-winter periods of researched years were favourable for hyssop growth and overwintering (Table 2). Shoots and buds freezing, plants death was not observed. Weather conditions during researched years were different. Thus, 2018 can be described as dry year, 2019 - average dry year, and 2020 - favourable year for moisture. 
During all researched years since mid-April, due to low relative humidity and drought, upper soil layers dried up quickly and conditions for hyssop growth became more difficult. Slight rainfall did not mitigate drought effects, so drip irrigation was used from the end of April.

Table 2. Meteorological data of experimental site for long years, 2018, 2019 and 2020.

\begin{tabular}{|c|c|c|c|c|c|c|c|c|c|c|c|c|c|}
\hline \multicolumn{2}{|c|}{ Months } & Jan. & Feb. & Mar. & Apr. & May & June & July & Aug. & Sep. & Oct. & Nov. & Dec. \\
\hline \multirow{3}{*}{$\begin{array}{l}\text { Long } \\
\text { term }\end{array}$} & temp. & -3.1 & -1.8 & 2.6 & 10.2 & 16.5 & 20.4 & 22.3 & 21.8 & 16.9 & 10.3 & 4.4 & -0.9 \\
\cline { 2 - 16 } & hum. & 87 & 82 & 79 & 73 & 67 & 68 & 61 & 62 & 70 & 76 & 83 & 86 \\
\cline { 2 - 16 } & precip. & 36 & 35 & 30 & 32 & 44 & 54 & 58 & 41 & 39 & 22 & 36 & 45 \\
\hline \multirow{4}{*}{2018} & temp. & -0.2 & -0.6 & -1.1 & 15.8 & 21.7 & 24.3 & 25.3 & 25.3 & 18.3 & 12.9 & 1.3 & 0.0 \\
\cline { 2 - 15 } & hum. & 85 & 84 & 82 & 61 & 60 & 53 & 64 & 44 & 60 & 65 & 80 & 87 \\
\cline { 2 - 15 } & precip. & 41 & 54 & 79 & 2 & 32 & 22 & 71 & 1 & 55 & 14 & 26 & 31 \\
\hline \multirow{3}{*}{2019} & temp. & 1.3 & 1.4 & 7.6 & 11.9 & 17.8 & 23.9 & 23.4 & 25.0 & 19.4 & 11.8 & 7.3 & 4.2 \\
\cline { 2 - 14 } & hum. & 84 & 82 & 74 & 73 & 62 & 54 & 56 & 49 & 63 & 77 & 86 & 87 \\
\cline { 2 - 14 } & precip. & 45 & 8 & 4 & 52 & 56 & 63 & 37 & 30 & 5 & 25 & 11 & 34 \\
\hline \multirow{3}{*}{2020} & temp. & 1.5 & 2.9 & 7.7 & 10.2 & 14.4 & 22.0 & 24.4 & 23.8 & 20.4 & 15.1 & 4.8 & 3.1 \\
\cline { 2 - 13 } & hum. & 86 & 82 & 76 & 70 & 73 & 73 & 60 & 65 & 64 & 77 & 86 & 86 \\
\cline { 2 - 13 } & precip. & 16 & 41 & 1 & 18 & 38 & 104 & 37 & 0 & 72 & 15 & 5 & 22 \\
\hline
\end{tabular}

Researching dynamics of hyssop growth processes during generative period stated that maximum plants height was reached in the third year of life $(37.4-83.9 \mathrm{~cm})$, while minimum height was reached in the first year of vegetation $-24.9-55.9 \mathrm{~cm}$. Starting from the second year of hyssop life, number of vegetative-generative shoots in the bush grew. So, in the second year their average number was 45-80 pieces, and in the third - 66-95 pieces (Fig. 1.)

Highest hyssop plant's weight is also stated in the third year of life $\left(659.4-1218.4 \mathrm{~g} / \mathrm{m}^{2}\right)$ the lowest - in the first year $\left(264.3-445.3 \mathrm{~g} / \mathrm{m}^{2}\right)$. Moreover, under conditions of cutting $H$. officinalis plants leaves at the end of June (beginning of flowering phase), we observed shoots growth by $30-50 \mathrm{~cm}$ and their flowering during last decade of August - beginning of September. However, due to lower temperatures, formed flowers were smaller, seeds did not ripen. Phytomass yield in this case was twice lower compared to the first mowing.

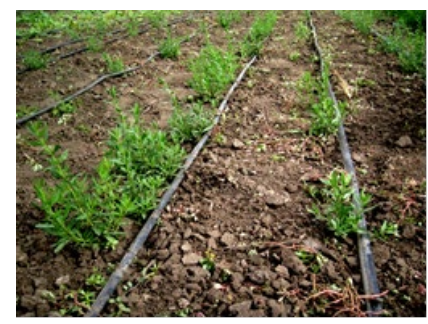

Fig. 1. Hyssop plants during the first year of life.

We have revealed the difference between plants biometric parameters depending on fertilizer and growing method (Table 3).

The most significant increase was reached by implementing N30P30 broadcast and N30P30 with irrigation, in this case, one plant had 70-76 shoots, plants height reached 59.9-69.5 cm, and plants weight was $836.5-884.8 \mathrm{~g} / \mathrm{m} 2$ (depending on plants irrigation method). 
Researches showed that growing hyssop by irrigation method $80-70-70 \% \mathrm{MHC}$, floral material yields in absolutely dry weight was $41.8 \mathrm{c} / \mathrm{ha}$, and by irrigation method $90-80-70 \%$ $\mathrm{MHC}-43.0 \mathrm{c} / \mathrm{ha}$ (average for 2018-2020 years). Comparing irrigation methods with each other, it should be noted that irrigation method $80-70-70 \% \mathrm{MHC}$ in efficiency was close to $90-80-70 \%$ MHC, because average yield levels of hyssop in these variants were significantly the same $\left(\mathrm{LSD}_{05}\right.$ on Factor $\left.\mathrm{B}-3.87 \mathrm{c} / \mathrm{ha}\right)$. Therefore, to form hyssop floral material yields, it is enough to grow crop using irrigation method $80-70-70 \% \mathrm{MHC}$.

Table 3. Hyssop capacity parameters (average for 2018-2020 years).

\begin{tabular}{|c|c|c|c|c|c|}
\hline Fertilizer (A) & $\begin{array}{l}\text { Height, } \\
\mathrm{cm}\end{array}$ & $\begin{array}{c}\text { Stalks } \\
\text { number, } \\
\text { pcs }\end{array}$ & $\begin{array}{c}\text { Bush } \\
\text { diameter, } \\
\mathrm{cm}\end{array}$ & $\begin{array}{c}\text { Plant } \\
\text { weight, } \\
\mathrm{g} / \mathrm{m}^{2}\end{array}$ & $\begin{array}{l}\text { Crop } \\
\text { yield, } \\
\text { c/ha }\end{array}$ \\
\hline \multicolumn{6}{|c|}{ Moisture level (B) $-80-70-70 \% \mathrm{MHC}$} \\
\hline 1. Control (without fertilizer) & $31.0 \pm 5.0$ & $47 \pm 7$ & $18 \pm 3$ & $\begin{array}{c}486.6 \pm 98 \\
4\end{array}$ & $32.3 \pm 5.9$ \\
\hline 2. $\mathrm{N}_{60} \mathrm{P}_{60}$ broadcast & $46.3 \pm 5.0$ & $60 \pm 7$ & $27 \pm 3$ & $\begin{array}{c}620.9 \pm 98 \\
4\end{array}$ & $40.6 \pm 5.9$ \\
\hline $\begin{array}{l}\text { 3. } \mathrm{N}_{30} \mathrm{P}_{30} \text { broadcast }+\mathrm{N}_{30} \mathrm{P}_{30} \text { with } \\
\text { irrigation }\end{array}$ & $59.9 \pm 5.0$ & $70 \pm 7$ & $33 \pm 3$ & $\begin{array}{c}836.5 \pm 98 \\
4\end{array}$ & $52.6 \pm 5.9$ \\
\hline Mean value & 45.7 & 58.7 & 25.9 & 648.0 & 41.8 \\
\hline \multicolumn{6}{|c|}{ Moisture level (B) - 90-80-70\% MHC } \\
\hline 1. Control (without fertilizer) & $42.5 \pm 5.1$ & $52 \pm 6$ & $23 \pm 3$ & $\begin{array}{c}506.2 \pm 105 \\
3\end{array}$ & $33.8 \pm 6.1$ \\
\hline 2. $\mathrm{N}_{60} \mathrm{P}_{60}$ broadcast & $56.9 \pm 5.1$ & $67 \pm 6$ & $33 \pm 3$ & $\begin{array}{c}633.9 \pm 105 \\
3\end{array}$ & $41.5 \pm 6.1$ \\
\hline $\begin{array}{l}\text { 3. } \mathrm{N}_{30} \mathrm{P}_{30} \text { broadcast }+\mathrm{N}_{30} \mathrm{P}_{30} \text { with } \\
\text { irrigation }\end{array}$ & $69.5 \pm 5.1$ & $76 \pm 6$ & $38 \pm 3$ & $\begin{array}{c}884.8 \pm 105 . \\
3\end{array}$ & $53.7 \pm 6.1$ \\
\hline Mean value & 56.3 & 65.1 & 31.4 & 675.0 & 43.0 \\
\hline
\end{tabular}

Appliance of mineral fertilizers together with drip irrigation increased hyssop flower mass yield. Thus, when applying mineral fertilizers, yield increased to 7.7-20.3 c/ha. The highest dry floral materials yield of 52.6-53.7 c/ha was obtained in the variant where $50 \%$ of mineral fertilizers dose was applied together with broadcast and $50 \%$ with irrigation water, in compliance with irrigation method of $80-70-70 \%$ MHC and $90-80-70 \%$ MHC.

Thus, in conditions of Mykolaiv region we have estimated success and prospects for hyssop (Hyssopus officinalis) cultivar 'Markiz' growth, which maximum biometric indicators were formed in the third year of life. On average during 2018-2020 years, optimal parameters of hyssop capacity (the largest number of shoots per plant 70-76 pieces, with plant height $59.9-69.5 \mathrm{~cm}$, plant weight $836.5-884.8 \mathrm{~g} / \mathrm{m}^{2}$ ) were noted when applying mineral fertilizers $\mathrm{N}_{60} \mathrm{P}_{60}(50 \%$ broadcast and $50 \%$ with irrigation water).

Research results were simultaneously tested with authors participation during 20182020 years in LLC "New Technologies" in the framework of project for biological reclamation of anthropogenically transformed lands, where hyssop crops were grown on area of 0.4 hectares. They were based upon the best option with the following elements of growing technology: plants sowing in the second decade of October, irrigation method 80$70-70 \%$ MHC, application of mineral fertilizers $\mathrm{N}_{60} \mathrm{P}_{60}(50 \%$ broadcast and $50 \%$ with irrigation water). Obtained results showed that projective plant cover in the third year of hyssop growth reached $75 \%$ and more, bushes density growth degree at damaged areas was high. Plants number varied from 2 to 4 pieces per unit of measured area. Plants height reached $60-80 \mathrm{~cm}$, bush diameter was $40-50 \mathrm{~cm}$, bushes were closed together during the third year of growth, forming a dense vegetation cover. Studies within the limits of tested reclamation method showed hyssop flower mass yield at the level of $48.1 \mathrm{c} / \mathrm{ha}$. 


\section{Conclusion and discussion}

Considering bioecological hyssop peculiarities and its adjustment to soil and climatic conditions of Mykolaiv region, it might be successfully grown aimed at recultivating degraded soils, alkali soils, sloping lands, local landscaping of technologically polluted areas, which will promote improvement of anthropogenically transformed ecosystems.

To implement such practical measures comprehensive approach should be used while selecting agronomic measures for growing crops by applying fertilizers $\left(\mathrm{N}_{60} \mathrm{P}_{60}\right.$ broadcast, $\mathrm{N}_{30} \mathrm{P}_{30}$ broadcast $+\mathrm{N}_{30} \mathrm{P}_{30}$ with irrigation water during boot stage) and retaining soil moister per 30-40 cm depth on the level of $80-70-70 \%$ MHC.

In these circumstances, stable agrophytocenosis is formed with optimal plants capacity parameters and crops of dry floral materials at the level of 52.6-53.7 c/ha. After the first mowing at the end of June, shoots are growing and flowering during the last August decade and beginning of September. However, phytomass yield is twice lower compared to the first mowing.

Obtained results of these researches are part of suggestions for rational use of land resources, protecting land degradation and desertification, submitted by Mykolaiv State Agricultural Research Station of Institute of Irrigated Agriculture of National Academy of Agrarian Sciences to the Department of Ministry of Agrarian Policy of Mykolaiv region and can be used for planning and practical implementation for biological reclamation of various types of damaged lands.

\section{References}

1. Litalien, A., \& Zeeb, B. (2019). Curing the earth: A review of anthropogenic soil salinization and plant-based strategies for sustainable mitigation. Sci Total Environ, (698), 134235. https://doi.org/10.1016/j.scitotenv.2019.134235

2. Dhankher, O.P., Doty, S.L., Meagher, R.B., \& Pilon-Smits, E. (2011). Biotechnological approaches for phytoremediation. Plant biotechnology and agriculture. Academic Press, Oxford, 309-328.

3. Fathiazad, F., \& Hamedeyazdan, S. (2011). A review on Hyssopus officinalis L. Composition and biological activities. Afr. J. Pharm. Pharmacol, (5), 1959-1966. https://doi.org/10.5897/AJPP11.527

4. Borrelli, F., Pagano, E., Formisano, C., Piccolella, S., Fiorentino, A., Tenore, G. C., Izzo, A. A., Rigano, D., \& Pacifico, S. (2019). Hyssopus officinalis subsp. aristatus: An unexploited wild-growing crop for new disclosed bioactives. Industrial Crops and Products, 140, 111594. https://doi.org/10.1016/j.indcrop.2019.111594

5. Alinezhad, H., Azimi, R., Zare, M., Ebrahimzadeh, M.A., Eslami, S., Nabavi, S.F., \& Nabavi, S.M. (2013). Antioxidant and antihemolytic activities of ethanolic extract of flowers, leaves and stems of Hyssopus officinalis L. var. angustifolius. International Journal of Food Properties, (16), 1169-1178. https://doi.org/10.1080/10942912.2011.578319

6. Soleimani, H., Barzegar, M., Sahari, M.A., \& Naghdi Badi, H. (2011). An investigation on the antioxidant activities of Hyssopus officinalis L. and Echinacea purpurea L. plant extracts in oil model system. J. Med. Plants., (10), 61-72.

7. Moro, A., Zalacain, A., de Hurtado, M.J., \& Carmona, M. (2011). Effects of agronomic practices on volatile composition of Hyssopus officinalis L. essential oils. Molecules, 16, 4131-4139. https://doi.org/10.3390/molecules16054131 
8. Dumacheva, E.V., Cherniavskih, V.I., Markova, E.I., Filatov, S.V., Tokhtar, V.K., Tokhtar, L.A., Pogrebnyak, T.A., Horolskaya, E.N., Gorbacheva, A.A., Vorobyova, O.V., \& Glubsheva, T.N. (2017). Biological resources of the Hyssopus 1 on the south of European Russia and prospects of its introduction. International Journal of Green Pharmacy, 11(3), 476-480.

9. Gonceariuc, M., \& Balmus, Z. (2013). Diversity of the essential oil content and chemical composition of Hyssopus officinalis L. genotypes. Muzeul Olteniei Craiova. Oltenia. Studii şi comunicări. Ştiinţele Naturii, 29(1), 71-77.

10. Kizil, S., Güler, V., Kirici, S., \& Turk, M. (2016). Some agronomic characteristics and essential oil composition of Hyssop (Hyssopus officinalis L.) under cultivation conditions. Acta scientiarum Polonorum. Hortorum cultus. Ogrodnictwo, 15, 193-207. 